armaments, arms control and disarmament. Compiles detailed studies on multilateral peace operations, military expenditure, arms transfers and arms embargoes.

Address: Signalistgatan 9, SE-169 70 Solna, Sweden.

Website: http://www.sipri.org

Director: Dr Bates Gill.

\section{Transparency International}

Founded 1993. Non-partisan global civil society organization seeking to create change towards a world free of corruption. Global priorities: combating corruption in politics, public contracting and the private sector; international anti-corruption conventions; poverty and development.
Address: Alt-Moabit 96, 10559 Berlin, Germany.

Website: http://www.transparency.org

Director: Huguette Labelle.

\section{Woodrow Wilson International Center for Scholars}

Founded in 1968 by an act of Congress as a memorial to former US president Woodrow Wilson. Non-partisan, it promotes and develops relations between policy-makers and academic scholars. Research covers most public policy areas, specializing in the field of international affairs.

Address: One Woodrow Wilson Plaza, 1300 Pennsylvania Ave., NW, Washington, D.C., 20004-3027, USA.

Website: http://www.wilsoncenter.org

Director: Lee H. Hamilton. 